\title{
Assessing the Safety of Heritage Buildings using CPTED Elements
}

\author{
Shahrul Yani Said, Risca Mering \\ Faculty of Architecture, Planning and Surveying, \\ Universiti Teknologi MRA, Shah Alam, Selangor,40450, Malaysia \\ shahrulyani@uitm.edu.my, riscabuteca@gmail.com: \\ Tel: +60104241563
}

\begin{abstract}
A good design considered the safety elements are the fundamental approach in ensuring natural surveillance. This study aims to assess the safety elements in conserved heritage buildings by utilizing CPTED elements as assessment tools. The objective of the study is to determine whether the original design or the conservation work considered crime prevention aspect in the design. Elements used in CPTED formed an intensive Pro-forma checklist used in evaluating selected heritage building for this study. The assessment carried out using a scorecard system where the result indicates that all three buildings lack in consideration of preventive crime mechanism in their design consideration.
\end{abstract}

Keywords: CPTED; safe heritage area; building conservation; an assessment tool

eISSN: 2398-4287 @ 2019. The Authors. Published for AMER ABRA cE-Bs by e-International Publishing House, Ltd., UK. This is an open access article under the CC BYNC-ND license (http://creativecommons.org/licenses/by-nc-nd/4.0/). Peer-review under responsibility of AMER (Association of Malaysian Environment-Behaviour Researchers), ABRA (Association of Behavioural Researchers on Asians) and cE-Bs (Centre for Environment-Behaviour Studies), Faculty of Architecture, Planning \& Surveying, Universiti Teknologi MARA, Malaysia.

DOI: https://doi.org/10.21834/e-bpj.v4i12.1922

\subsection{Introduction}

Crime Prevention through Environmental Design (CPTED) is a method in reducing or avoiding crime from happening. The basis of CPTED is the four principles; natural surveillance, natural access control, territorial reinforcement and maintenance, and management. The crime prevention system is the mechanism or order in a building or surrounding to prevent the crime in that area. Besides, the people involved in the crime also can be easily caught. Crime prevention is a signifincant problem or topic that has to be solved or discussed because it can affect our quality of life. Security or safety is a complicated notion in urban environments only by taking specific measures (Yadzanfar and Nazari, 2015).

Several crime prevention mechanisms can be installed in the building or building surround such as the wireless sensor network system. This system is a very efficient or effective crime prevention method that can be preventing an opportunity for crime to occur. Crime proofing includes the implementation of a system that can sense the surrounding area, especially the entrance door condition by using the camera that connected with the space sensor. So, the space sensor captures images of the person entering the space. Besides, the system also records the occurring event in the location that has been installed in the space sensor. Moreover, a doorbell mounted with an emergency button and the image input unit relates to the space sensor mounted nearly of the entrance door to output an image of a person entering or surround the space detected by the space sensor to the image output unit.

A more elaborate definition made by Cozens (2008) is a crime that is highly complex and has many issues to discuss. The occurring of crime related to them how the design or layout of the surrounding environment. So, it is useful for the planner or any party that involves in development to approach crime prevention through environmental design in their planning or method of design. Crime prevention through environmental design including the surrounding area of the building, for example, road layout, house design, surveillance, territoriality, car parking, communal space, management and maintenance and physical security (Armitag, 2000).

Atlas (2015) argues that crimes such as vandalism, terrorism, burglary, shoplifting, employee theft, assault, and espionage endanger lives and threaten the built environment. He felt that security and safety as a design consideration have often been inadequately

eISSN: 2398-4287 @ 2019. The Authors. Published for AMER ABRA cE-Bs by e-International Publishing House, Ltd., UK. This is an open access article under the CC BYNC-ND license (http://creativecommons.org/licenses/by-nc-nd/4.0). Peer-review under responsibility of AMER (Association of Malaysian Environment-Behaviour Researchers), ABRA (Association of Behavioural Researchers on Asians) and cE-Bs (Centre for Environment-Behaviour Studies), Faculty of Architecture, Planning \& Surveying, Universiti Teknologi MARA, Malaysia. DOI: https://doi.org/10.21834/e-bpj.v4i12.1922 
addressed and poorly funded. Atlas (2015) also argues that to the urban design professionals or any creator of public and private spaces should support the most efficient, least expensive way to provide security is during the earliest phases of development. However, the current threat to the existing environment leads to his belief that the urban designer must now integrate and combine security concepts, architectural elements, and security technologies into a balanced holistic solution. The integration can best happen by obtaining a grasp of fundamental security design concepts, principles, and strategies.

Safe and secure community is one of the important strategy in Sustainable Development Goals (SDG), a blueprint to achieve a better and sustainable future for all, initiated by the United Nation in 2015. Moreover, Malaysia has adopted CPTED strategy in introducing Safe City concept in many of its new development. This study supports those initiatives.

This paper discusses the safety consideration in the design or conservation work of selected heritage buildings in Malaysia. The assessment made is based on physical observation of the premises by using a guided scorecard using CPTED elements as the assessed variables.

\subsection{Heritage asset and crime protection}

According to Sandbhor \& Botre (2013), heritage architecture is a design or creation that can represent a vital role in world history and culture. It is also having its significant value or richness in it. So, it is essential to keep the heritage building in a safe condition or avoid it from any crime. Meanwhile, Ahmad (2006) define heritage building as an archaeological, historical, scientific sites, structures, artistic, architectural value. It represents the previous culture, whether religious or secular, historic quarters in urban or rural built-up areas that have significant or value that still exist in a valid form or remains found in the earth. Heritage buildings can represent, at one extreme, the high cost, old and rare examples of the built environment that give great significance to the national history, identity and culture. Heritage is an older building made from material, and the construction methods that are no longer used in this era. The skills to carry out the work are not universally available, which means the specialized for the heritage building not easy to find.

Santos, (2004) defined heritage building is the existing building that has significant value and gives more benefit to the community and society in that area. The high value of heritage depends on its age. The older the building the higher its value. Meanwhile, Rafidee \& Hasbollah, (2015) defined heritage buildings are part of human design to be an icon, local identity, cultural significance, background, source of memory, historical event and the tourism industry for the nation or the country.

Crime prevention through environmental design strategy is the technique or action that be taken to influence the offender's decision before involving in crime. As mentioned earlier, CPTED strategy can be implemented through crime prevention through environment design principle which is natural surveillance, mechanical surveillance, organized surveillance, territorial reinforcement, natural access control, and maintenance (Huxford, 2004). The strategy through natural surveillance, as mentioned by Huxford (2004) is the design characteristics that enhance visibility and allow more straightforward observation by the routine uses of the property. Moreover, natural surveillance is to maximize visibility in the observation of criminal activities. Then, the strategy through mechanical monitoring by installed the action of the security system in the home, office, and environment surrounding (Figure 1). Besides, an organized surveillance strategy is by using a police or security guard to keep our property safe (Durham city, 2005).
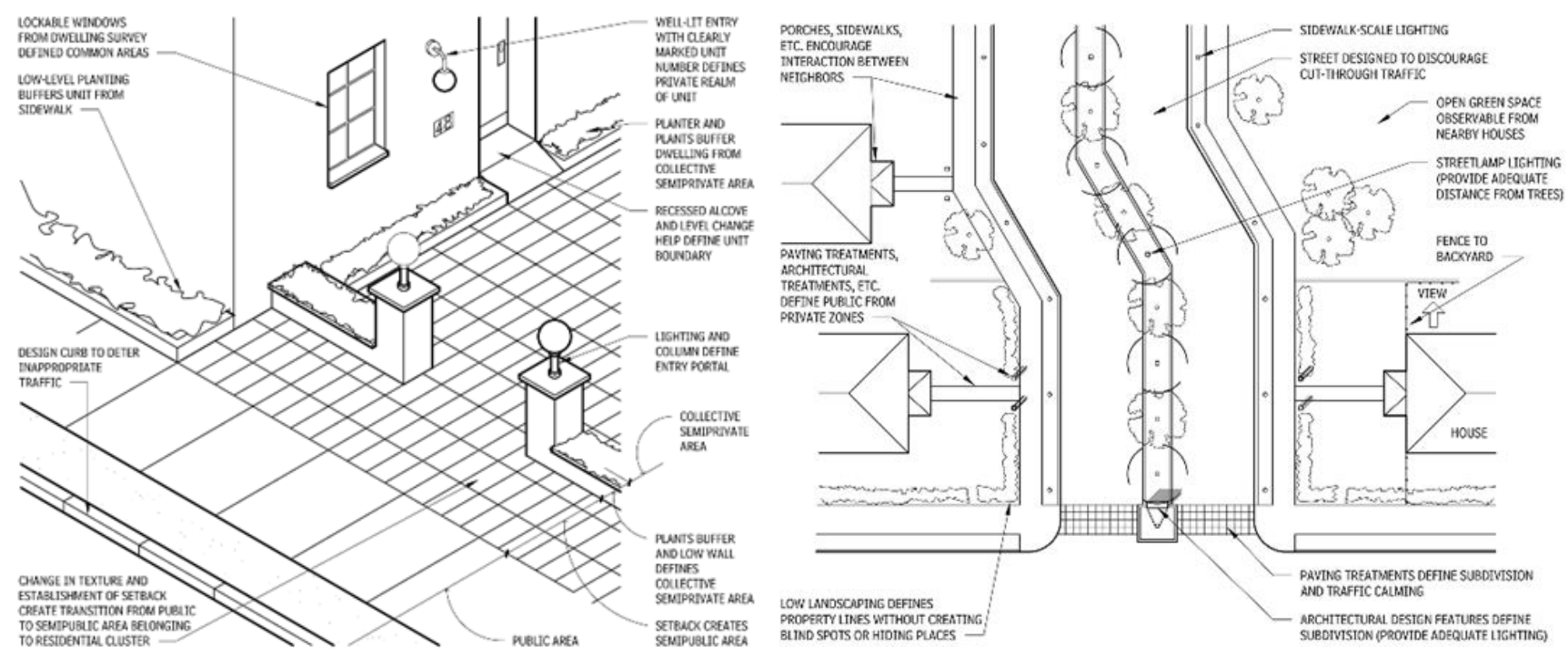

Figure 1: Security layering of spaces Source: Atlas, 2018

The strategy through territorial reinforcement can be explained with the use of fencing in residential houses to show ownership. However, the fence should not prevent the resident from observing the environment surrounding their building. Furthermore, the usage of signage that displays the name or address in the property will serve as territorial demarcation. 
In Durham CPTED Manual (2005), natural access control is a design concept directed primarily at decreasing crime opportunity. Use fencing material to discourage access to the unmonitored area. Then, they can control the number of the access point or the number people into a home can be made by installing a mechanical or electronic system in the building (Huxford, 2004).

Another strategy is through maintenance. A well-maintained premises indicates the presence of the owner, hence prevent the crimes. It can be a message to criminals that property is in care. For example, to maintain the plant in front of the house make sure it not overgrowth and to ensure the height of the bushes and trees is controlled and does not create an opportunity as a hiding place for criminal and create blind spot from the surveillance.

\subsection{Methodology}

The physical assessment carried out to three selected heritage buildings; Bangunan Sultan Abdul Samad (BSAS), the Church of Our Lady Lourdes (COLL) and Galeri Sultan Abdul Aziz (GSAA) in Klang. The selected buildings are conserved and are in use. The study is to assess whether safety consideration was part of the conservation strategy. The survey was carried out for three days in November 2018.

The quantitative data collected for this case study uses the CPTED elements assessment proforma designed for the study. The scoring system for each element used to quantify the score for each case study to give value to the score. The ratings are based on assessment rubrics (Table 2; p3) to define the existence of the elements. Observation is also noted, and photographic evidence in the form of a digital photo is collected to explain further and justify the score given.

The assessment carried out is the physical assessment of what the researcher can see at the site. Scoring is based on a Likert scale of 0 to 4 (non-existence to Very good). A similar scoring method was used in numerous studies for physical assessment such as carried out in Townscape Assessment for Heritage Urban Areas in Malaysia (Said \& Samadi, 2018) and Townscape assessment: The development of a practical tool for monitoring and assessing visual quality in the built environment (Reeve, 2008).

Twenty- five (25) elements of CPTED are grouped into three categories. The distributions are as follow:

\begin{tabular}{|c|c|c|}
\hline $\begin{array}{c}\text { Part A: } \\
\text { Environmental Quality/ Condition and } \\
\text { Streetscape }\end{array}$ & $\begin{array}{c}\text { Part B: } \\
\text { Building Quality/ Condition }\end{array}$ & $\begin{array}{c}\text { Part C: } \\
\text { Safety and Surveillance }\end{array}$ \\
\hline Accessibility & 12. Wall & 23. Close circuit television \\
\hline Landscaping & Protecting of door & 24. Organised surveillance \\
\hline Road/ pedestrian walkway condition & Protecting of window & 25. Gated and guarded \\
\hline Signage & 15. Lighting & \\
\hline Legibility & Signage & \\
\hline Street lighting & Building layout & \\
\hline Car parking & Building material/ structure & \\
\hline Fencing & Sightlines & \\
\hline Territorial definition & 20. Building entrance & \\
\hline 10. Street furniture/ structure & Access & \\
\hline 11. Management and maintenance & 22. Maintenance & \\
\hline
\end{tabular}

*Adapted from Said \& Samadi,2018

\subsection{Assessment}

The assessment carried out is based on the researcher's expert observation of what can be seen physically on the site. The variables used were based on the CPTED requirements. Thus the assessment is made to measure the level of implementation of CPTED in the selected buildings. The evaluation carried out using variables and rubrics as follows:

Table 2: CPTED based assessment rubrics

\begin{tabular}{|c|c|c|c|c|c|}
\hline Elements & 0 & 1 & 2 & 3 & 4 \\
\hline Accessibility & Not clear. & $\begin{array}{l}\text { Exist but not functioning to } \\
\text { support the passive crime } \\
\text { prevention system in the } \\
\text { building }\end{array}$ & $\begin{array}{l}\text { Exist and functioning but } \\
\text { does not support the } \\
\text { crime prevention system }\end{array}$ & $\begin{array}{l}\text { Exist and support the crime } \\
\text { prevention system but } \\
\text { lacking in certain criteria. }\end{array}$ & $\begin{array}{l}\text { Exist and support the } \\
\text { crime prevention system }\end{array}$ \\
\hline Landscaping & No landscape & $\begin{array}{l}\text { Exist but not functioning to } \\
\text { support the passive crime } \\
\text { prevention system in the } \\
\text { building }\end{array}$ & $\begin{array}{l}\text { Exist and support but only } \\
\text { in certain area. }\end{array}$ & $\begin{array}{l}\text { Exist and support the crime } \\
\text { prevention system but lack } \\
\text { in certain criteria }\end{array}$ & $\begin{array}{l}\text { Exist and support the } \\
\text { crime prevention system }\end{array}$ \\
\hline $\begin{array}{l}\text { Road/ } \\
\text { pedestrian } \\
\text { walkway } \\
\text { condition }\end{array}$ & $\begin{array}{l}\text { Not support the } \\
\text { crime prevention } \\
\text { system }\end{array}$ & $\begin{array}{l}\text { Pedestrian walkways are } \\
\text { not provided on both sides } \\
\text { of the road, no appropriate } \\
\text { distance lighting along the } \\
\text { pedestrian in the night }\end{array}$ & $\begin{array}{l}\text { Presence of street } \\
\text { furniture at pedestrian } \\
\text { walkway but no } \\
\text { appropriate distance } \\
\text { lighting along the } \\
\text { pedestrian at night }\end{array}$ & $\begin{array}{l}\text { Appropriate distance } \\
\text { lighting along the pedestrian } \\
\text { in the night, street furniture } \\
\text { at pedestrian walkways but } \\
\text { not adequate. }\end{array}$ & $\begin{array}{l}\text { Appropriate distance } \\
\text { lighting along the } \\
\text { pedestrian in the night, } \\
\text { adequate street furniture } \\
\text { at pedestrian walkways }\end{array}$ \\
\hline
\end{tabular}




\begin{tabular}{|c|c|c|c|c|c|}
\hline Signage & Not exist & $\begin{array}{l}\text { Exist but not legible, } \\
\text { material not suitable and } \\
\text { durable }\end{array}$ & $\begin{array}{l}\text { Exist but cannot read } \\
\text { from far and cannot read } \\
\text { at night }\end{array}$ & $\begin{array}{l}\text { Exist and can read clearly } \\
\text { but not at the night }\end{array}$ & $\begin{array}{l}\text { Exist, clear and visible to } \\
\text { read }\end{array}$ \\
\hline Legibility & Not exist. & $\begin{array}{l}\text { Exist but not clearly } \\
\text { understood. }\end{array}$ & $\begin{array}{l}\text { Exist but has obstacles } \\
\text { to prevent familiarity }\end{array}$ & $\begin{array}{l}\text { Exist and can be } \\
\text { understood }\end{array}$ & $\begin{array}{l}\text { Clear design, ease } \\
\text { movement from one } \\
\text { point to another }\end{array}$ \\
\hline Street lighting & Not exist. & $\begin{array}{l}\text { Exist but not functioning and } \\
\text { vandalised. }\end{array}$ & $\begin{array}{l}\text { Exist and only some are } \\
\text { functioning and not } \\
\text { adequate. }\end{array}$ & $\begin{array}{l}\text { Exist and all well functioned } \\
\text { but not adequate easily } \\
\text { vandalised. }\end{array}$ & $\begin{array}{l}\text { Adequate and well } \\
\text { function }\end{array}$ \\
\hline Car parking & $\begin{array}{l}\text { Not support the } \\
\text { crime prevention } \\
\text { system. }\end{array}$ & $\begin{array}{l}\text { Not facing the building, } \\
\text { inadequate lighting at night, } \\
\text { no CCTV, not easily view } \\
\text { from the street and near } \\
\text { building. }\end{array}$ & $\begin{array}{l}\text { Facing the building, easily } \\
\text { view, inadequate lighting } \\
\text { at night, no CTTV. }\end{array}$ & $\begin{array}{l}\text { Facing the building, easily } \\
\text { view, adequate lighting, } \\
\text { inadequate CCTV. }\end{array}$ & $\begin{array}{l}\text { Facing the building, easily } \\
\text { view, well lighted, } \\
\text { adequate CCTV. }\end{array}$ \\
\hline Fencing & Not exist. & $\begin{array}{l}\text { Exist at certain area, not } \\
\text { well maintenance, easily } \\
\text { vandalise and climb. }\end{array}$ & $\begin{array}{l}\text { Exist around the building } \\
\text { but not well maintenance. }\end{array}$ & $\begin{array}{l}\text { Exist around the building, } \\
\text { not easily climb and } \\
\text { vandalise but not well } \\
\text { maintenance. }\end{array}$ & $\begin{array}{l}\text { Exist, anticlimb, strong } \\
\text { and well maintained }\end{array}$ \\
\hline $\begin{array}{l}\text { Territorial } \\
\text { definition }\end{array}$ & Not exist. & $\begin{array}{l}\text { Exist at certain area, easily } \\
\text { vandalise and not well } \\
\text { maintenance. Not clear }\end{array}$ & $\begin{array}{l}\text { Exist, not clear read and } \\
\text { well maintenance and } \\
\text { easily vandalise. }\end{array}$ & $\begin{array}{l}\text { Exist, not clear at night, not } \\
\text { easily vandalise but not well } \\
\text { maintenance. }\end{array}$ & $\begin{array}{l}\text { Define the territory of the } \\
\text { space }\end{array}$ \\
\hline $\begin{array}{l}\text { Street } \\
\text { furniture/ } \\
\text { structure }\end{array}$ & Create an obstacles & $\begin{array}{l}\text { Not in a proper Location, } \\
\text { sizing, arrange the furniture } \\
\text { and structure }\end{array}$ & $\begin{array}{l}\text { Lack in location, sizing } \\
\text { the furniture or structure }\end{array}$ & $\begin{array}{l}\text { The location, size and } \\
\text { arrangement of the furniture } \\
\text { or structure is good but not } \\
\text { secure }\end{array}$ & $\begin{array}{l}\text { Well located, good size } \\
\text { of furniture and structure } \\
\text { that provides security }\end{array}$ \\
\hline $\begin{array}{l}\text { Management } \\
\text { and } \\
\text { maintenance }\end{array}$ & $\begin{array}{lr}\text { There } & \text { no } \\
\text { management and } \\
\text { maintenance } \\
\text { occurred. }\end{array}$ & $\begin{array}{l}\text { Maintenance occurred but } \\
\text { not frequent and detail }\end{array}$ & $\begin{array}{l}\text { Management and } \\
\text { maintenance occurred } \\
\text { frequent but not detail. }\end{array}$ & $\begin{array}{l}\text { Management and } \\
\text { maintenance occurred but } \\
\text { only in certain criteria. }\end{array}$ & $\begin{array}{l}\text { Well maintained and } \\
\text { managed }\end{array}$ \\
\hline Wall & $\begin{array}{l}\text { Not support crime } \\
\text { prevention system. }\end{array}$ & All blind wall. & $\begin{array}{l}\text { Blind wall with windows } \\
\text { at the site }\end{array}$ & $\begin{array}{l}\text { Some Wall with openings } \\
\text { overlooking the outside }\end{array}$ & $\begin{array}{l}\text { Enough Wall with } \\
\text { openings overlooking the } \\
\text { outside }\end{array}$ \\
\hline $\begin{array}{l}\text { Door } \\
\text { Protection }\end{array}$ & $\begin{array}{l}\text { Not exist (Grill, lock, } \\
\text { natural access } \\
\text { control) }\end{array}$ & $\begin{array}{l}\text { Exist but easily to } \\
\text { vandalised, not function } \\
\text { well and installed only } \\
\text { certain door }\end{array}$ & $\begin{array}{l}\text { Exist good condition but } \\
\text { installed in certain } \\
\text { window. }\end{array}$ & $\begin{array}{l}\text { Exist and good condition } \\
\text { apply in all door but easily } \\
\text { vandalise. }\end{array}$ & $\begin{array}{l}\text { Door protection present } \\
\text { and good natural access } \\
\text { control }\end{array}$ \\
\hline $\begin{array}{l}\text { Window } \\
\text { protection }\end{array}$ & $\begin{array}{l}\text { Not exist (Grill and } \\
\text { lock). }\end{array}$ & $\begin{array}{l}\text { Exist but easily to } \\
\text { vandalised, not function } \\
\text { well and installed only } \\
\text { certain window. }\end{array}$ & $\begin{array}{l}\text { Exist good condition but } \\
\text { installed in certain } \\
\text { window }\end{array}$ & $\begin{array}{l}\text { Presence of window } \\
\text { protection and good natural } \\
\text { access control but } \\
\text { inadequate }\end{array}$ & $\begin{array}{l}\text { Adequate number of } \\
\text { window protection and } \\
\text { good natural access } \\
\text { control }\end{array}$ \\
\hline Lighting & Not exist. & $\begin{array}{l}\text { Exist but not function or } \\
\text { well maintenance. }\end{array}$ & $\begin{array}{l}\text { Exist and only certain } \\
\text { lighting functioned but } \\
\text { not adequate. }\end{array}$ & $\begin{array}{l}\text { Exist and all function but } \\
\text { not adequate. }\end{array}$ & $\begin{array}{l}\text { Exist and all function } \\
\text { Enough to serve as } \\
\text { passive crime prevention }\end{array}$ \\
\hline $\begin{array}{l}\text { Signage on } \\
\text { building }\end{array}$ & Not exist & $\begin{array}{l}\text { Exist but not legible, } \\
\text { material not suitable and } \\
\text { durable }\end{array}$ & $\begin{array}{l}\text { Exist but cannot read } \\
\text { from far and cannot read } \\
\text { at night }\end{array}$ & $\begin{array}{l}\text { Exist and can read clearly } \\
\text { but not at the night }\end{array}$ & $\begin{array}{l}\text { Exist, clear and visible to } \\
\text { read }\end{array}$ \\
\hline Building layout & $\begin{array}{l}\text { Not support crime } \\
\text { prevention system. }\end{array}$ & $\begin{array}{l}\text { Building layout not well } \\
\text { organised, not facing the } \\
\text { street, not provided visibility } \\
\text { at difference angle of vision }\end{array}$ & $\begin{array}{l}\text { Well organised, not } \\
\text { facing the street, not } \\
\text { provided visibility at } \\
\text { difference angle of vision }\end{array}$ & $\begin{array}{l}\text { Well organised, facing the } \\
\text { street, but not provided } \\
\text { visibility at difference angle } \\
\text { of vision }\end{array}$ & $\begin{array}{l}\text { Well organised, facing } \\
\text { the street, visible at } \\
\text { difference angle of vision }\end{array}$ \\
\hline $\begin{array}{l}\text { Building } \\
\text { material/ } \\
\text { structure }\end{array}$ & $\begin{array}{l}\text { Not support crime } \\
\text { prevention system }\end{array}$ & $\begin{array}{l}\text { Similar material use } \\
\text { throughout the building with } \\
\text { added detail as } \\
\text { demarcation of spaces }\end{array}$ & $\begin{array}{l}\text { Different material use in } \\
\text { paving to redirect the } \\
\text { traffic, but not visible }\end{array}$ & $\begin{array}{l}\text { The design of structure } \\
\text { define the territory of the } \\
\text { building but fail to } \\
\text { differentiate territory }\end{array}$ & $\begin{array}{l}\text { Paving treatments, } \\
\text { plantings, and } \\
\text { architectural design } \\
\text { features such as } \\
\text { columned gateways can } \\
\text { guide visitors away from } \\
\text { private areas }\end{array}$ \\
\hline Sightlines & $\begin{array}{l}\text { Not support crime } \\
\text { prevention system. }\end{array}$ & $\begin{array}{l}\text { Design elements too large } \\
\text { and with corners that serve } \\
\text { as blind spot and could } \\
\text { shield attacker }\end{array}$ & $\begin{array}{l}\text { Big and tall columns that } \\
\text { provide minimum } \\
\text { surveillance from inside } \\
\text { of the building }\end{array}$ & $\begin{array}{l}\text { Small number of vision } \\
\text { impediments, organized } \\
\text { surveillance helps to guard } \\
\text { the blind spots }\end{array}$ & $\begin{array}{l}\text { Low hedges or planters, } \\
\text { small trees, wrought iron } \\
\text { or chain-link fences, } \\
\text { transparent reinforced } \\
\text { glass, lawn or flower } \\
\text { beds, benches allow } \\
\text { users to see and be seen } \\
\text { and usually discourage } \\
\text { crime and vandalism }\end{array}$ \\
\hline $\begin{array}{l}\text { Building } \\
\text { entrance }\end{array}$ & $\begin{array}{l}\text { Not support crime } \\
\text { prevention system. }\end{array}$ & Sightlines not clear. & $\begin{array}{l}\text { Clear from closed } \\
\text { distance and not provide } \\
\text { crime prevention system. }\end{array}$ & Clear but not at night. & $\begin{array}{l}\text { Partially visible from the } \\
\text { street and clearly visible } \\
\text { from the driveway or } \\
\text { parking lot }\end{array}$ \\
\hline Access & $\begin{array}{l}\text { Not support the } \\
\text { crime prevention } \\
\text { system. }\end{array}$ & $\begin{array}{l}\text { There no CCTV, organized } \\
\text { guard, natural control } \\
\text { access and grill. }\end{array}$ & $\begin{array}{l}\text { There are CCTV, } \\
\text { organized guard, natural }\end{array}$ & $\begin{array}{l}\text { There are CCTV, organized } \\
\text { guard, natural access }\end{array}$ & $\begin{array}{l}\text { Presence of adequate } \\
\text { number of CCTV, }\end{array}$ \\
\hline
\end{tabular}




\begin{tabular}{|c|c|c|c|c|c|c|}
\hline & & & & $\begin{array}{l}\text { access but not function } \\
\text { and adequate. }\end{array}$ & $\begin{array}{l}\text { functioned but not } \\
\text { adequate in number. }\end{array}$ & $\begin{array}{l}\text { organized guard, natural } \\
\text { access is functioning }\end{array}$ \\
\hline Maintenance & None & & $\begin{array}{l}\text { Maintenance occurred but } \\
\text { not frequent and detail. }\end{array}$ & $\begin{array}{l}\text { Maintenance occurred } \\
\text { frequent but not detail }\end{array}$ & $\begin{array}{l}\text { Maintenance occurred but } \\
\text { only in certain criteria. }\end{array}$ & $\begin{array}{l}\text { Good maintenance } \\
\text { management }\end{array}$ \\
\hline $\begin{array}{l}\text { Close circuit } \\
\text { television }\end{array}$ & CCTV not exist. & & Exist but not function. & $\begin{array}{l}\text { Only exist at the outdoor } \\
\text { or indoor. }\end{array}$ & $\begin{array}{l}\text { Exist and function well but } \\
\text { not adequate. }\end{array}$ & $\begin{array}{l}\text { Presence of adequate } \\
\text { number of CCTV, }\end{array}$ \\
\hline $\begin{array}{l}\text { Organised } \\
\text { surveillance }\end{array}$ & $\begin{array}{l}\text { Organised } \\
\text { surveillance } \\
\text { exist. }\end{array}$ & not & $\begin{array}{l}\text { Only guarded at the gate } \\
\text { and not } 24 \text { hours guarded. }\end{array}$ & $\begin{array}{l}\text { Guarded at the gate, } \\
\text { around the building but } \\
\text { not } 24 \text { hours. }\end{array}$ & $\begin{array}{l}\text { Guarded at the gate and } 24 \\
\text { hours. }\end{array}$ & $\begin{array}{l}\text { Guarded at the gate and } \\
\text { with on-foot surveillance } \\
\text { scheduled regularly }\end{array}$ \\
\hline $\begin{array}{l}\text { Gated and } \\
\text { guarded }\end{array}$ & none & & $\begin{array}{l}\text { The gate exists but don't } \\
\text { have lock, easily to climb } \\
\text { and not guarded. }\end{array}$ & $\begin{array}{l}\text { The gate exists but don't } \\
\text { have lock, easily to climb } \\
\text { but guarded by security. }\end{array}$ & $\begin{array}{l}\text { Gate has lock, not easily } \\
\text { climb but not guarded } 24 \\
\text { hours }\end{array}$ & $\begin{array}{l}\text { Gate has lock, not easily } \\
\text { climb and guarded } 24 \\
\text { hours }\end{array}$ \\
\hline
\end{tabular}

\subsection{Results and Discussion}

The case study carried out in the three selected buildings shows that the overall effect for safety and crime prevention measure in heritage buildings are good with the score of more than 50 per cent (Figure 2.0).

\section{TOTAL SCORE FOR CPTED ASSESSMENT IN HERITAGE BUILDINGS}

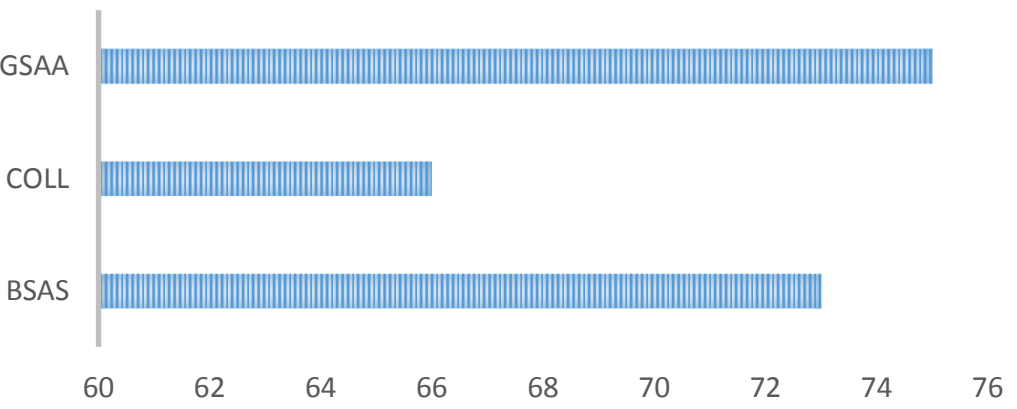

Fig 2.0 Overall score for safety aspect based on the score sheet

All the buildings, although built post-safety-crime-prevention design approach was equipped with enough counter-surveillance measures that were added later on. The result indicates that GSAA and BSAS, being two historical landmarks scored more than $70 \%$ marks on safety based on CPTED criteria. The two buildings are listed heritage buildings and under the protection of the National Heritage Department. Whilst COLL serves as a religious building and privately maintained scored $65 \%$. The distribution of marks for the case studies are as follows.

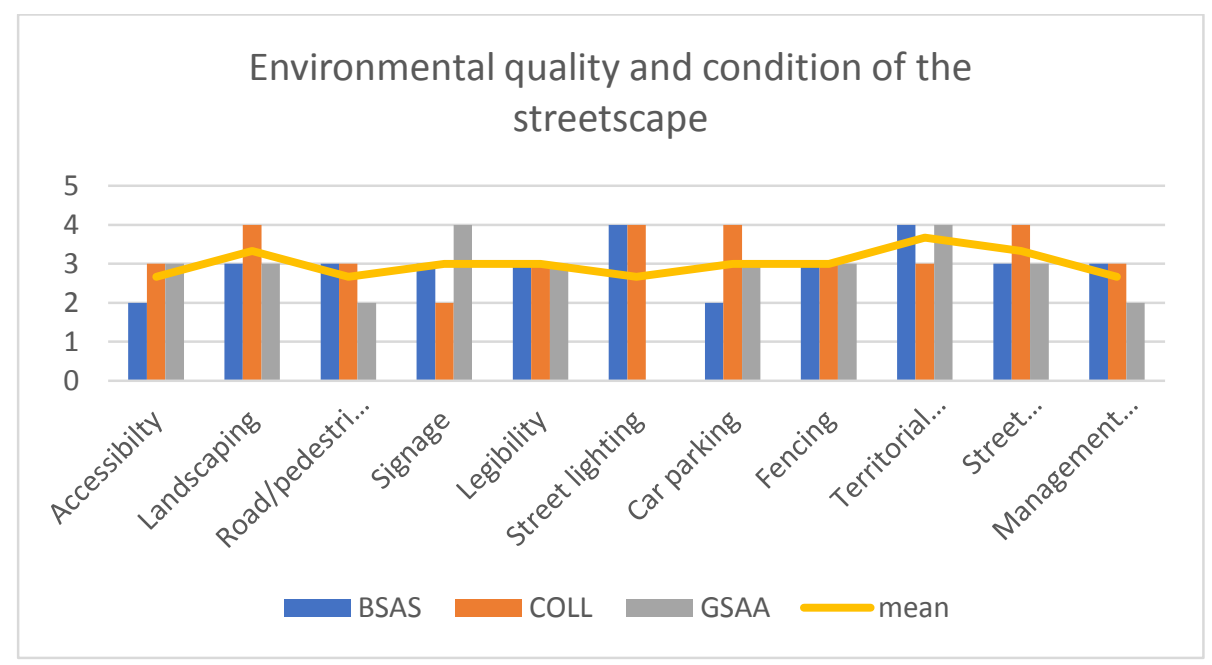

Fig 3.0 The score for the assessment of Environmental Quality/ Condition and Streetscape

CPTED safety assessment carried out indicates that for GSAA, the safety consideration that could be seen physically involving environmental quality and condition of the observed streetscape is at $55 \%$ of overall score (Figure 3.0 and 4.0 ). There was no street 
lighting near the building (rating 0 ) that could contribute to safety issues at night. On the contrary, the gated condition, proper signage, and demarcation of territorial division help to create a conducive safe area. Other variables for environmental quality/condition of the streetscape recorded more than minimum score, which can be concluded that the safety design consideration is there.

Crime prevention is an element of the services that design for security providers and strategy applied in the earliest possible stage of the design process. Crime prevention through environmental design compromises five principles which are natural surveillance, natural access control, territorial reinforcement, maintenance, and management. Natural surveillance is the design that ensuring the resident able to observe the surrounding area of their home. For example, the design or position of the front door faces onto the street. This statement proves by Paul Cozens \& Love,(2015), which is the natural surveillance be an opportunity for residents to observe the street are facilitated by the design of the road, the location of entrances, and the placement of windows.

BSAS scored 4 for territorial definition and street lighting which also above the mean aggregate. However, the car parking and accessibility to the building are minimal due to the function of the building in which explains the 2 marks scored. The new design for the River of Life project helps to create a passive surveillance system that helps to provide a safe environment for the building naturally.

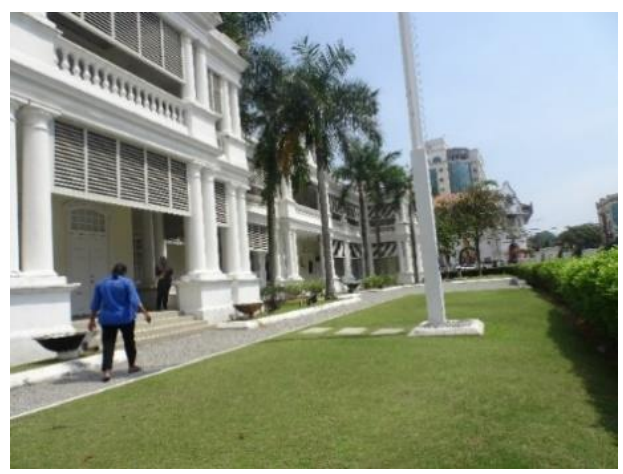

Fig 4.0 Clear territorial definition, trimmed landscape and clear access at GSAA

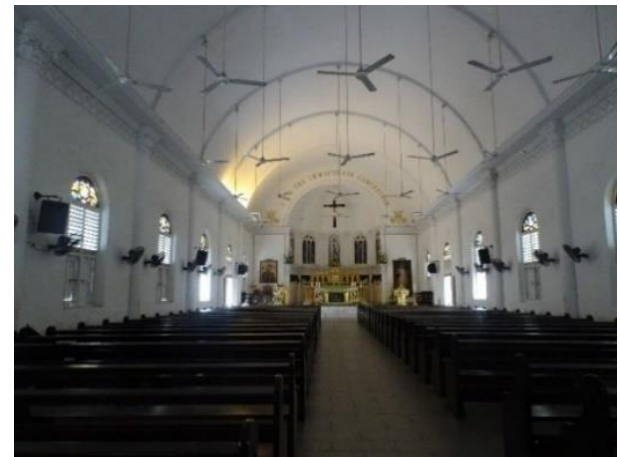

Fig 5.0 Wall with a number of windows provide surveillance from inside the building at CoLL

On the other hand, the Church of Our Lady Lourdes (CoLL) aggregated scores are above the mean score. However, the signage condition is not easily seen and read that resulted in the low score achieved. However, the design of the walls with some windows helps as natural access surveillance (Figure 5.0). This building is easy to access and provided with car parking facilities. The well-designed landscape also contributed to passive monitoring of this place.

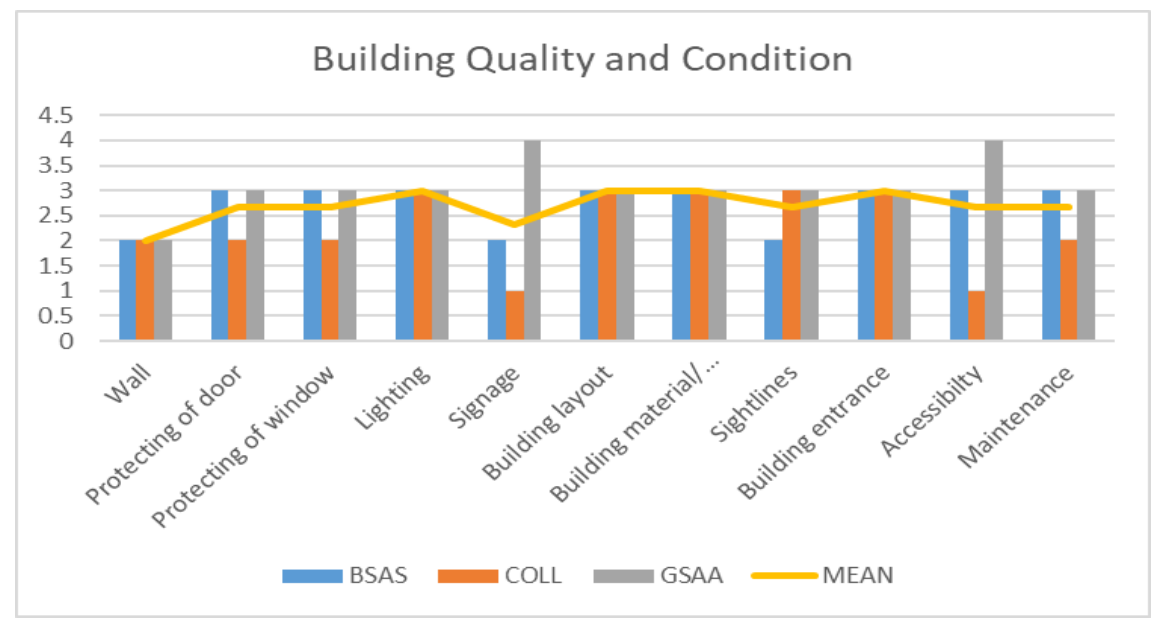

Fig 6.0. The score for the assessment of Building Quality and Condition

Figure 6.0 indicates that many aspects of natural surveillance were taken into consideration in the design of the building. Nonetheless, blind walls surrounding the building prevented natural surveillance and scored only 2 for all case studies. The building has good accessibility between spaces and signage that helps to navigate users. The usage of keycard and passcode on doors restrict the accessibility to some private areas whilst several large windows provide natural surveillance from inside the building.

GSAA scored the 3 points and above for every CPTED elements in the building and is considered having the best accessibility and signage among the three buildings with the full score, higher than the mean score for both categories. The signage in this building helps to navigate people from one space to another, and the exit and entrance sign is visible to assist in guiding people. GSAA was built as a 
government building and it is designed to be accessible for the public, hence the perfect score. As an essential building, GSAA is well gated and guarded (Figure 6.0)

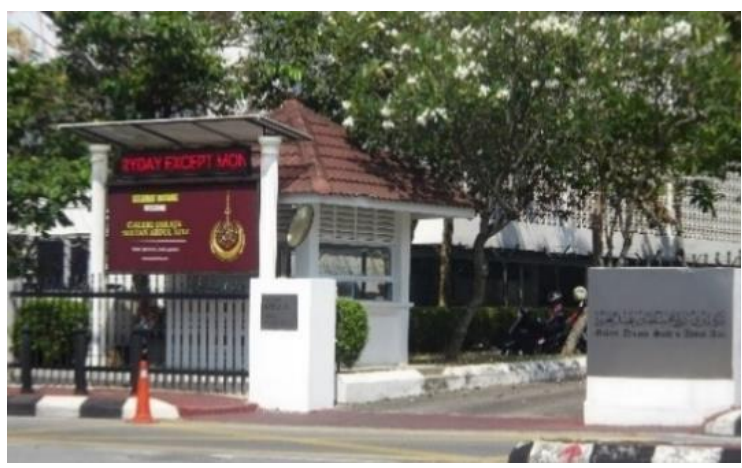

Fig 7.0 Gated and guarded facility (GSAA)

The building quality and condition of BSAS, on the other hand, has a nearly perfect score of 3 points for every element except for a lower score for the blind wall, signage, and sightlines. BSAS is a majestic, iconic landmark of Kuala Lumpur. It has large and tall columns and many blind spot corners that can be some severe impediments to the feeling of being safe. The design provides poor sightlines for safety consideration of the building. Besides that, most of the envelope walls are blind walls that prevent direct outside view. The signage is present but poorly done that it is not easily spotted and read from far; thus the low score achieved.

Nonetheless, the safety of this building mostly depends on its added on-site surveillance devices. The assessment pointed out that GSAS and COLL are fully equipped with an on-site surveillance system. Both buildings are gated and guarded by security officers. CCTVs were installed at most of the corners and blind spot areas. BSAS has no organized surveillance system, although equipped with CCTV and guarded. This well-known landmark is designed and prepared for visitors who mostly are tourists. Heavily imposed security system, on the other hand, will create some tension for them. Thus, this building depends on natural surveillance to ensure its safety

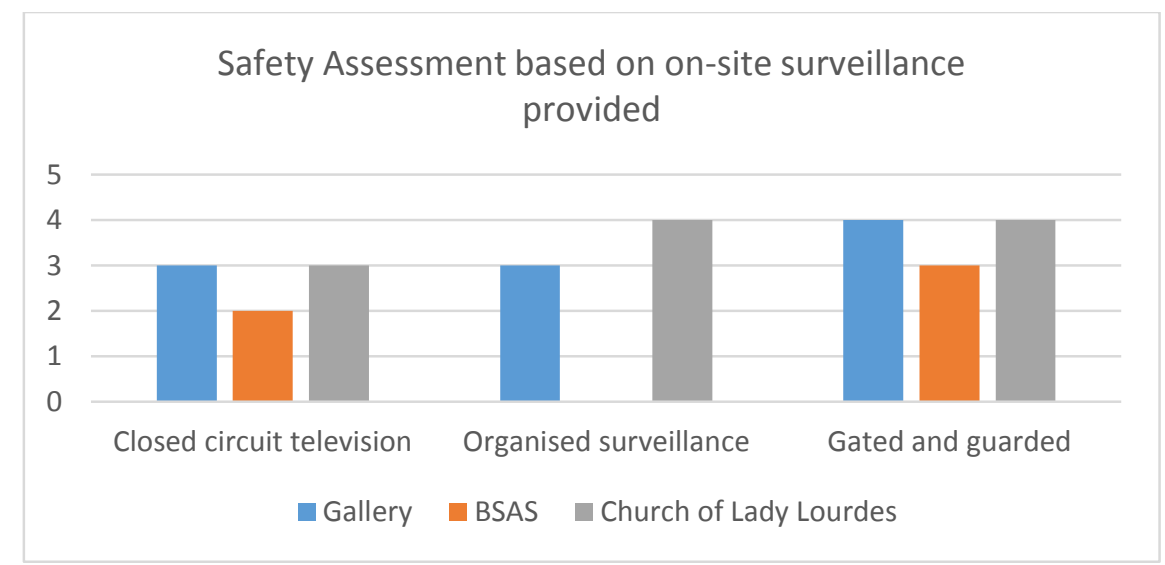

Fig 8.0.: The score for on-site surveillances provided for the buildings

\subsection{Conclusion}

The CPTED elements assessed for the three buildings showed some consideration of the in the original design of the building, whether intentionally or not. The landscape on most of the case study buildings provide a clear territorial definition and provide natural protection. Presence of mechanical surveillance such as CCTV has also improved the security of the place. Nonetheless, the lack of safety elements found such as the accessibility to the building, the condition of the road or pedestrian path, the street lighting, the car parking, the management and maintenance, the wall, the protection of door and window, the building material or structure, the sightlines and a properly organized surveillance.

Thus, considerations on the additional passive and active surveillance system in heritage buildings should be implemented. The design of the heritage building, foremost, the listed building shall not be disturbed; hence, additional non-glaring surveillance could help in ensuring the safety of these national assets. The introduction of more landscaping could also help to define the territory of the building and serves as a boundary. Besides that, concealed road blocked the visibility from one point to another. The visibility should be improved by lighting and/ or the use of a reflective surface such as a mirror. Furthermore, if there is a need for the concealed or isolated route to the buildings such as service or loading area, it should be designed to incorporate visibility.

Based on the finding, it is recommended that the accessibility in the building should be clearly addressed. For example; the use of walkways and landscaping in order to direct visitors to the proper entrance, and away from private areas. Secondly to improve, road 
and pedestrian access. The width of the road must comply with existing guidelines adopted by the Local Authority and road network must be inter-connected and has a clear hierarchy. It is vital to ensure the pedestrian walkway is not encouraged to be connected to the dead-end road, maintenance regularly, visible directly from nearby premises, not obstructed by any structure and provide natural lighting.

Then for street lighting provide adequate lighting to backlines, street, pedestrian, hidden, present entrapment, and dark places. Provide proper lighting during the night so that the face of a person can be seen from $10 \mathrm{~m}$ and recorded by CCTV. Meanwhile, the car parks should be designed within easy view from the street, inside, nearby buildings and enable or easy natural surveillance. Next, the management and maintenance personnel should ensure that all areas of the building regularly or adequately managed and maintained. For the wall of the building ensure that avoid the blind wall.

Besides, ensure that the door and window have an access card, lock, and grill. Furthermore, there is a need to add closed-circuit television at shaded areas; places without bright visibility space create entrapment areas. Organized surveillance should be hired in the building, so the safety of the building is secured.

In conclusion, the study indicates that there are needs to increase the safety of the heritage buildings in Malaysia. Natural surveillance and CPTED elements could be an easy guide to achieve the safety level as needed. Conserved heritage building often is an essential building that stored a great important history of the past. Therefore, it is vital to maintain its safety and security to ensure the sustainability of heritage.

\section{Acknowledgements}

The authors gratefully acknowledge the help of the Ministry of Education (MoE) of Malaysia in providing the Fundamental Research Grant Scheme (FRGS 27/2017) and Universiti Teknologi MARA.

\section{References}

Armitage, R. (2000). An Evaluation of Secured by Design Housing In West Yorkshire. Policing and Reducing Crime Unit Briefing Note 7/00. London: Home Office.

Atlas, R. I (2015) 21st Century CPTED: Designing for Critical Infrastructure and Crime Prevention. 2nd Edition: CRC Press Taylor \& Francis Group.

Cozens, P., \& Love, T. (2015). A Review and Current Status of Crime Prevention through Environmental Design (CPTED). Journal of Planning Literature, 30(4), 393412. https://doi.org/10.1177/0885412215595440

Huxford, R. (2004). Safer places - The Planning System and Crime Prevention. Proceedings of the ICE - Municipal Engineer, 157, 5-107. https://doi.org/10.1680/muen.2004.157.4.227

Johar, F. B., Hosni, N. B., Maisarah, P., Zulkarnain, B., \& Planning, R. (2005). The Potential Of Applying Crime Prevention Through Environmental Design ( CPTED ) Principles In Malaysian Residential Neighbourhood.

Rafidee, H., \& Hasbollah, B. (2015). A Conceptual Framework for Conserving Heritage Buildings in Malaysia from the Perspective of Facilities Management, 5, $45-51$.

Reeve et al (2008) Evaluating the THI. Townscape Heritage Initiative Conference. Machester

Said, SY, Samadi, Z (2018) Melaka Streetscape Evolution: The six years journey Asian Journal of Quality of Life, v3(11) p93-102

Sandbhor \& Botre, (2013) A Systematic Approach Towards Restoration Of Heritage Buildings- A Case Study. International Journal of Research in Engineering and Technology, 2 (03), 229-238. 2319-1163

Santos, S. P. (2004). Guide for the Structural Rehabilitation of Heritage Buildings.

Singapore: National Crime Prevention Council (2003). Crime Prevention Through Environmental Design Guidebook.

Yadzanfar and Nazari (2015) Proposed Physical-Environmental Factors Influencing Personal and Social Security in Residential Areas. Procedia - Social and Behavioral Sciences 201(2015) $224-233$ 